\title{
Pakistan's Timberline Forest Ecosystem Dynamics vis-a-vis Changing Climate Across Three Provinces (KPK, AJK and GB) Using GIS/RS Techniques
}

\author{
TARIQ MAHMOOD ${ }^{*}$, SARWAT NAZ MIRZA², SAEED GULZAR ${ }^{2}$, MOHAMMAD HANIF ${ }^{3}$ \\ ${ }^{1}$ University of Sargodha, Faculty of Agriculture \& Food Sciences, Department of Forestry College of Agriculture, Lahore- \\ Khushab Bypass, Main Road (Near Ludewala Jhaal) Sargodha, Punjab, Pakistan \\ ${ }^{2}$ PMAS-Arid Agriculture University, Department of Forestry and Range Management, Rawalpindi, Pakistan \\ ${ }^{3}$ PMAS-Arid Agriculture University, Department of Mathematics \& Statistics, Rawalpindi, Pakistan
}

\begin{abstract}
World's forests have always been under anthropogenic threats leading to instantaneous and sound supervision using satellite-based data collecting capabilities through GIS/RS. Timber line in Pakistan consists of sub-alpine forests and alpine pastures of KPK, AJK and GB. Research findings showed that earth's climate was changing rapidly than previously assumed, demanding the spatiotemporal dynamics analysis using GIS/RS techniques in prevalent climate change scenarios. Two separate methods were used; 1) Visual Interpretation of Supervised Classification Technique for AJK \& GB and 2) object Oriented Classification of Supervised Classification Technique for KPK. The primary data for T (max), T (min) \& Ppt. (1980-2013) was taken from PMD, Islamabad. Province wise data showed $15 \%$ change in forest cover area for timber line in both KPK (142780 Ha) \& AJK (24990 Ha), followed by GB (39267 Ha) as $13 \%$ across 2005-2014. The results calculated that the average upward shift in timberline was highest in KPK $(285 \mathrm{~m})$, followed by AJK $(233 \mathrm{~m})$ and GB (170m) across 2005-2014.The data also showed change in avg. $T$ (max) was $3.4^{\circ},-1.8^{\circ}$ and $0.6^{\circ} \mathrm{C}$, avg. $T$ (min) was $-2^{\circ},-1.5^{\circ}$ and $-2^{\circ} C$ while change in total precipitation was $88.5,-3.7$ and $75.5 \mathrm{~mm}$ for AJK, GB and KPK respectively. The Pearson's Correlation Co-efficient chart concluded that climatic factors showed a strong and positive correlation among themselves as well as with change in elevation. However, the correlation among climatic factors and change in forest cover area was weak concluding deforestation to be exclusively an anthropogenic phenomena. Change in elevation showed $a$ weak and negative correlation with change in area while all other correlations were non-significant.
\end{abstract}

Keywords: Timberline forests, Pakistan, Pearson's correlation, climate change, GIS/RS

\section{Introduction}

Land cover data play an important role in understanding and resolving various issues pertaining to the natural resource management including forests. Forests are an integral natural resource and should be preserved on main concern basis for sustainable ecological development. The practical application of GIS/RS was initiated in 1930 by means of aerial photographs and the launching of the first Earth Resources Technology Satellite (ERTS-1) in 1972 led to the monitoring of natural resources including forests in the world using GIS/RS techniques for land cover area analysis. Forest change detection mapping through satellite images was found to be the 'most influential surveying tool' for conservation organizations, local administration and the non-government organizations (Simoonga et al, 2009). Tree cover are changes monitoring was considered of utmost importance for the forest ecosystem directors (Mitasova et al, 1996). Growing levels of human disturbances have urged terrific heaviness on the forests. Therefore, instantaneous supervision and maintenance of the regional forests using modern tools and techniques was declared imperative (Rabindra et al, 2010) because forest ecosystem management requires precise and rationalized resource statistics. Satellite - based data collecting

*email: tariqmahmood870@yahoo.com 
capabilities have the potential to detect variations accurately and mapping can be done in modified ways. Despite the multiplicity of functions, a number of conclusions can be made about the importance of GIS in the field of forestry. Using remote sensing, particularly Light Detection and Ranging (LIDAR) to derive relevant forest characteristics for scientific forest management through Species Distribution Models were concluded to be the need of the hour (Rechsteiner et al, 2017). Mccall and Minang, (2005) critically evaluated the participatory GIS (PGIS) used in participatory mapping and planning for community-based natural resource management. Timber line in Pakistan consists of Subalpine forests and alpine pastures. Alpine Pastures located (above $3350 \mathrm{~m}$ ) in the north of the country i.e., in northern Hazara, Malakand Division of KPK and Gilgit, Baltistan \& Diamir districts of GB These includes alpine meadows and shrub formation including evergreen Junipers macropoda Boiss., Rhododendron arboretum Sm., Ephedra nebrodensis Tineo., Salix tetrasperma Roxb.and Lonicera spp Thunb. Sub-alpine forests (upto $3350 \mathrm{~m}$ ) are found in AJK, Upper Dir, Swat, Chitral, Hazara (KPK) and Gilgit (GB). Main species are Abies pindrow [(Royle ex D.Don)Royle] and Betula utilis D .Don., with undergrowth of Viburnum nervosum D. Don. and Salix tetrasperma Roxb.,(Bukhari et al, 2012). Research findings showed that earth's climate was changing rapidly than previously assumed and researchers were working actively to compute the climate change and its impacts on natural resources particularly forests all over the world by using various modern tools, techniques and methodologies including GIS/RS. Pakistan was rated amongst countries, highly exposed to the impacts of climatic events, particularly because of its arid conditions, agrarian economic base, resource scarcity, over exploitation and mismanagement of natural resources (LEADS, 2009). On the whole, impact of climate change on the forest networks of Pakistan can be depressing (Siddiqui et al, 1991). The study thus emphasizes, the assessment of the spatio-temporal dynamics (horizontal \& vertical distributional shifts across 2005-2014) of timberline in three provinces including KPK, GB and AJK using GIS/RS techniques in climate change trends of Pakistan.

\section{Materials and methods}

The study area comprised of timber line of Pakistan in three provinces of KPK, AJK and GB. As per availability of the satellite images, 17 Districts were analyzed through GIS/RS techniques including 07 Districts from Gilgit Baltistan (namely Baltistan, Gilgit, Astor, Ghizer, Ghanchi, Diamer and Hunzanagar), 07 Districts from Khyber Pakhtunkhwa (namely Chitral, Upper Dir, Battagram, Kohistan, Manshra, Shangla and Swat) and 03 Districts from Azad Jammu \& Kashmir (namely Neelam, Haveli \& Hattian). The data was analyzed statistically to calculate spatio- temporal changes in area (horizontal) and elevation (vertical) shift across 2005-2014. The primary data for change in climatic variables $(\mathrm{T}(\max ), \mathrm{T}(\mathrm{min})$ \& ppt.) during 1980-2013 (33 yrs) in timberline area (KPK, GB \& AJK) of Pakistan was obtained from Pakistan Meteorological Department Islamabad for Pearson's Correlation analysis using software "A language and environment for statistical computing by R. Core team (2016)" to find the trends of spatio-temporal changes in area (horizontal) and elevation (vertical) shift across 2005-2014 (10 years) in the study area.

\subsection{Study Area}

Area coverage coordinates (encompassing 2,15,000 sq. km) were :

1. Lat : $37 \odot^{\circ} 13^{\prime} 07^{\prime \prime} \mathrm{N}$ Lon: $70 \circ^{\circ} 49^{\prime} 49^{\prime \prime} \mathrm{E}$

2. Lat : $37 \circ 13$ ' 59 " N Lon: $77 \circ 53$ ' $50^{\prime \prime} \mathrm{E}$

3. Lat : $34{ }^{\circ} 07^{\prime} 07^{\prime \prime} \mathrm{N}$ Lon: $77^{\circ} 38^{\prime} 37^{\prime \prime} \mathrm{E}$

4 Lat : 34 '52 '09" N Lon: $700^{\circ} 57^{\prime} 42^{\prime \prime} \mathrm{E}$

Two separate methods were used including:

2.2 Visual Interpretation Method of Supervised Classification Technique for AJK \& GB 2.2.1 Materials

1. Google Earth Pro (Ver 4.2)

2. Google Earth Images of 2005 \& 2014 

3. Arc GIS Ver. 10.3
4. Pakistan Boundary:
Data Type: Shape files Feature Class
Shape file: F:ITBPRJ\Pakistan BoundarylExport_Output.shp
Projected Coordinate Sys: Lambert Conformal Conic, Meter unit, GCS-Everest (Pakistan)
5. Digital Elevation Model (DEM)
Downloaded from SRTM site, Single Band," Tiff", Resolution 30m, Pixel depth 16 Bit

\subsubsection{Methodology}

Google Earth images of 2005 \& 2014 for 7 districts of GB and 3 districts of AJK were processed using Google Earth Pro (4.2) software by applying the supervised classification technique. The images were already Geo-referenced and rectified. Boundary of the districts was procured from the Survey of Pakistan as given above. The timberline areas were digitized using Visual interpretation method of supervised classification technique and the processed files were saved as ".kHz" format. These files were imported into Arc GIS (10.3) software in the ".shp" format for further processing.

Area calculation of the timber line for both 2005 \& 2014 images was made using the tool Calculate Geometry (Hac) for finding the horizontal shifts.

Digital Elevation Model (DEM) written above was overlaid in Arc GIS and contours of $100 \mathrm{~m}$ interval were generated using the Spatial Analyst Tool. Point of highest elevations were marked in each district for both 2005 \& 2014 images to find the vertical shifts.

Separate map for each districts were prepared and then fit in to the provincial boundary for their respective provinces using Update Tool for data mergering in Arc GIS software for further analysis.

\subsection{Object Oriented Classification Method of Supervised Classification Technique for KPK 2.3.1 Materials}

1. SPOT -5 Images of 2005 \& 2014 were taken from SUPARCO, Pakistan

Resolution $=2.5 \mathrm{~m}($ Pan Sharpen as $5 \mathrm{~m})$, No. of Bands $=4$, Pixel Depth $=8 \mathrm{bit}$

Datum = D_WGS_1984

2. E - Cognition Developer Version 9.0 (64 Bit)

3. Arc GIS Ver. 10.3

4. Pakistan Boundary:

Data Type: Shape files Feature Class

Shape file: F:ITBPRJPakistan BoundarylExport_Output.shp

Projected Coordinate Sys: Lambert Conformal Conic, Meter unit, GCS-Everest (Pakistan)

5. Digital Elevation Model (DEM)

Downloaded from SRTM site, Single Band," tiff", Resolution 30m, Pixel depth 16 Bit

\subsubsection{Methodology}

SPOT-5 images of 2005 \& 2014 for 7 districts of KPK were procured from SUPARCO, Pakistan in ".img" files and opened in E-Cognition Developer for Object oriented Supervised Classification technique. The images were already Geo-referenced and rectified. Boundary of the districts was procured from the Survey of Pakistan as given above. The images were opened in E-Cognition Developer and various colors segments (Polygons) were generated using Segmentation Tool (Multiresolution segmentation---->Scale Parameter 30 size). For applying the Supervised Classification technique, Classification tool was used and various color segments were assigned rent classes as 1 . Forests 2, non-forest. Command of Apply was used to classify the timberline areas into Forested \& Non- Forested classes. These files were then exported into Arc GIS (10.3) software in the ".shp" format for further processing. These shape files were overlaid on original image for verification of the supervised classification into Forest \& Non-Forests. 
Area calculation of the timber line for both $2005 \& 2014$ images was made using the tool Calculate Geometry (Hac) for finding the horizontal shifts.

Digital Elevation Model (DEM) was overlaid in Arc GIS and contours of 100 meter interval were generated using the Spatial Analyst tool. Point of highest elevations was marked in each district for both $2005 \& 2014$ images to find the vertical shifts.

Separate map for each districts were prepared and then fit in to the provincial boundary for their respective provinces using Update Tool for data mergering in Arc GIS software for further analysis.

\section{Results and discussions}

Province wise data shows $15 \%$ change in forest cover area for timber line in both KPK (142780 Ha) \& AJK (24990 Ha), followed by GB (39267 Ha) as13\% across 2005-2014 (10 years) (Table 1, Fig 1-6). Results of ANOVA suggested a significant difference between the average change of forest cover area in different provinces ( $\mathrm{p}$-value $<0.05$ ). Fisher's LSD indicated significant difference between KPK and GB whereas AJK was found as non-significant to these (Figure 7).

Province wise data shows that the average upward shift in timberline was maximum in KPK (285 m), followed by AJK (233 m) and GB (170m) across 2005-2014 (10 years) (Table 2, Fig 1-6). Results of ANOVA suggested a non-significant difference between the average elevation change in different provinces (p-value<0.05). Fisher's LSD also indicated a non-significant difference between the each pair of provinces too (Figure 8).

Province wise data showed change in avg. T (max) was $3.4^{\circ},-1.8^{\circ}$ and $0.6^{\circ} \mathrm{C}$, avg. $\mathrm{T}(\min )$ was $2^{\circ},-1.5^{\circ}$ and $-2^{\circ} \mathrm{C}$ while change in total precipitation was $88.5,-3.7$ and $75.5 \mathrm{~mm}$ for $\mathrm{AJK}$, GB and KPK respectively (Table 3,4,5). The Pearson's Correlation Co-efficient chart for the 5 factors namely $\mathrm{T}(\max ), \mathrm{T}(\min )$, Precipitation, Change in forest cover area \& Change in elevation showed the highest values for $\mathrm{T}(\max )-\mathrm{T}(\min )$ as 0.88 , followed by Change in elevation-Ppt as $0.86, \mathrm{~T}(\max )-\mathrm{Ppt}$ as 0.73 and $\mathrm{T}(\mathrm{min})-\mathrm{Ppt}$ as 0.47 . A negative correlation though very little as -0.15 was estimated for Change in area-Change in elevation. The values for other correlation were found insignificant (Figure 9).

The average reduction in forest cover area was calculated as $14 \%$ while average upward shift of the timberline was found $230 \mathrm{~m}$ in the study area across 2005-2014 (10 years) using Geographic Information System (GIS/RS tools). Sakthivel et al. (2010) centers on the subject of estimation of changes in forest cover through GIS/RS in the Kalrayan hills of Tamil Nadu, eastern India. Sheikh et al. (2012) used GIS/RS techniques to analyze decrease in coniferous forests. The results proved that coniferous forests have been diminishing at the rate of $1.27 \% / y e a r$ since 1992 . Thus, there was a dire need for the conservation of these forests to avoid social and economic disturbances. Tan and Mu-yi, (2016) used GIS/RS techniques for finding the position of timberline appearing on 2900-3200 m.a.s.1 altitudes in Helan mountains, China. Dutta et al. (2014) highlighted the research gaps in hilly areas across the world including Himalayas after thoroughly reviewing timberline research work carried out in the mountain ranges of Europe, North America and Himalaya urging the application of GIS/RS in future. The results are consistent with the studies of various scientists highlighting the scientific management of the forests in present era using modern state of the art technological advancements as Geographical Information System (GIS/RS Techniques).

Province wise data showed $15 \%$ change in forest cover area for timber line in both KPK (14270 Hac) \& AJK (24990 Hac), followed by GB (39267 Hac) as $13 \%$ across 2005-2014 (10 years). The results were consistent with Adedeji et al. (2015) which revealed dramatic decline in the degree of the forests during 1984-2014 using multiple chronological data sets, , Olokeogun et al. (2014) considered that Forests decrease by $46.12 \%$ in 18 years study time, Mifta-ul-Shafiq et al. (2017) calculated a decrease in forests from $45.31 \%$ in 2002 to $44.61 \%$ in 2014, Khattak et al. (2015) found that, from 1990 to 2010, there was a significant decrease of $9.97 \%$ in vegetation and in contradiction with the work of Rawat and Kumar, (2015) which indicated that during the last two decades, vegetation had increased by $3.51 \%\left(9.39 \mathrm{~km}^{2}\right)$ and Raza et al. (2012) discussed that during 1998-2009, there was an increase of $2.83 \%$ in forest land in Abbotabad district of Khyber Pakhtunkhwa province in Pakistan. 
Province wise data showed that the average upward shift in timberline was maximum in KPK (285 $\mathrm{m})$, followed by AJK (233 m) and GB (170m) across 2005-2014 (10 years). The results were in consistent with the studies of Mihai (2007) estimated an increase in timberline elevations, Klinge et al. (2003) and Siddiqui (1994) anticipated that alterations in the physio-chemical nature of the earth's climate were liable to encompass a noteworthy blow to the forests and related ecosystems like alpine and sub-alpine forests causing them to move upward towards more northerly/southerly latitudes and up elevational gradient from their present locations. The results were in contradiction with Mamet et al. (2015) who_modeled the spatial distribution of forests and concluded that forest areas were extending additionally to south instead of real forest confines.

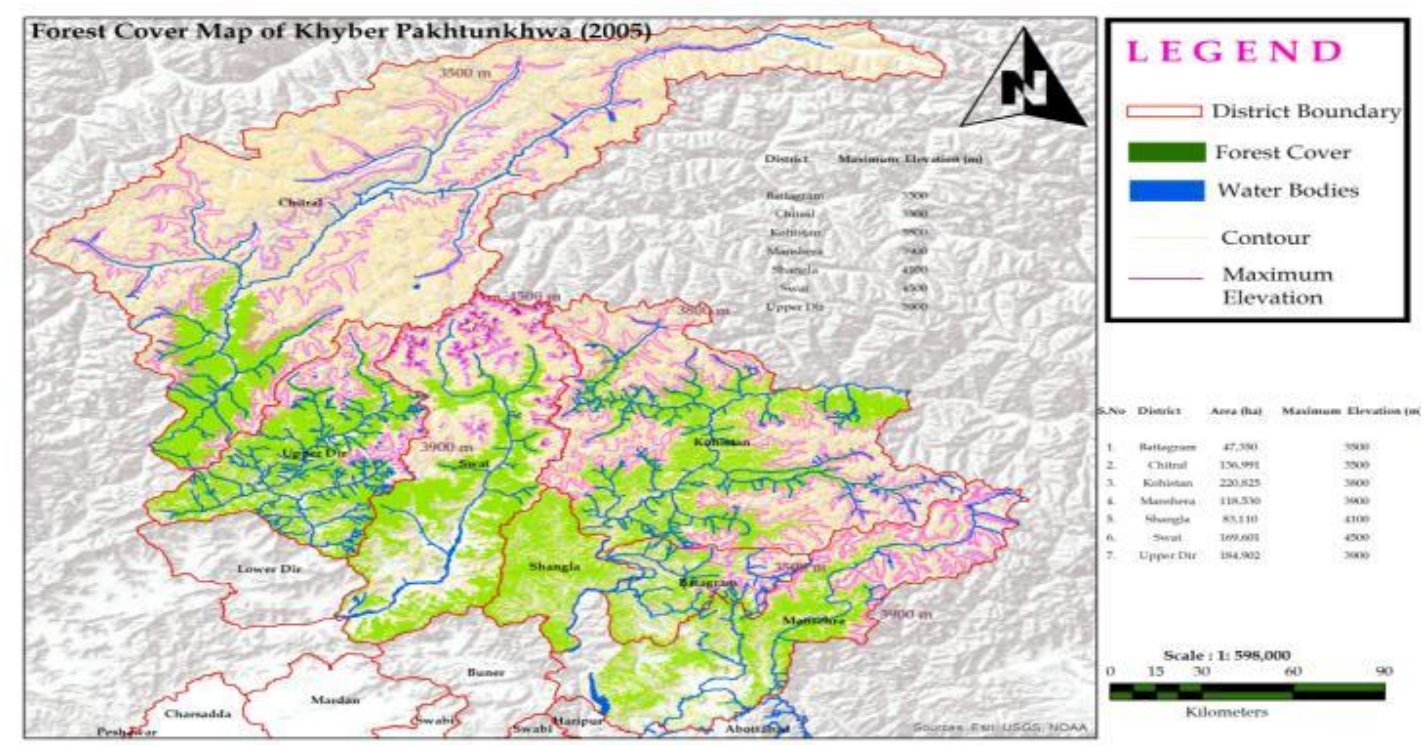

Figure 1. Forest cover \& elevation map of Khyber Pakhtunkwa (KPK) for 2005

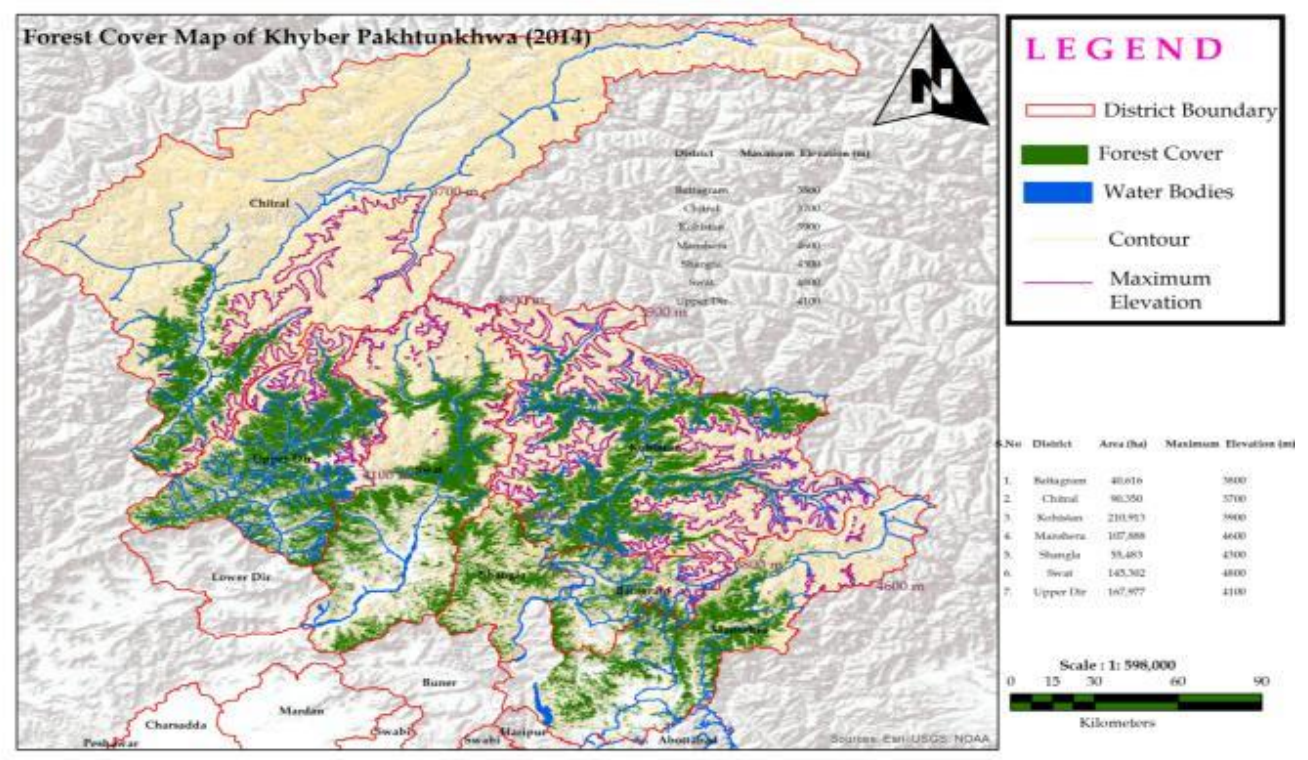

Figure 2. Forest cover \& elevation map of Khyber Pakhtunkwa (KPK) for 2014 

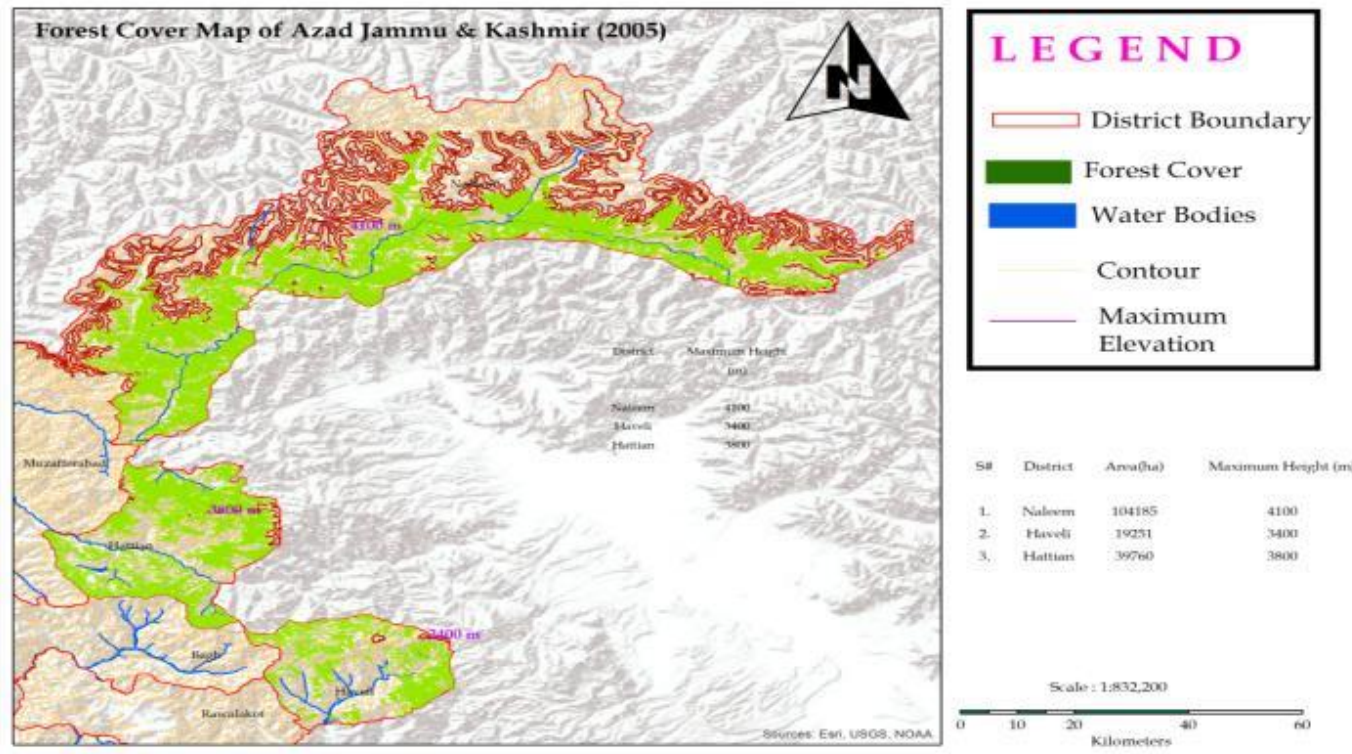

Figure 3. Forest cover \& elevation map of Azad J. \& Kashmir (AJK) for 2005
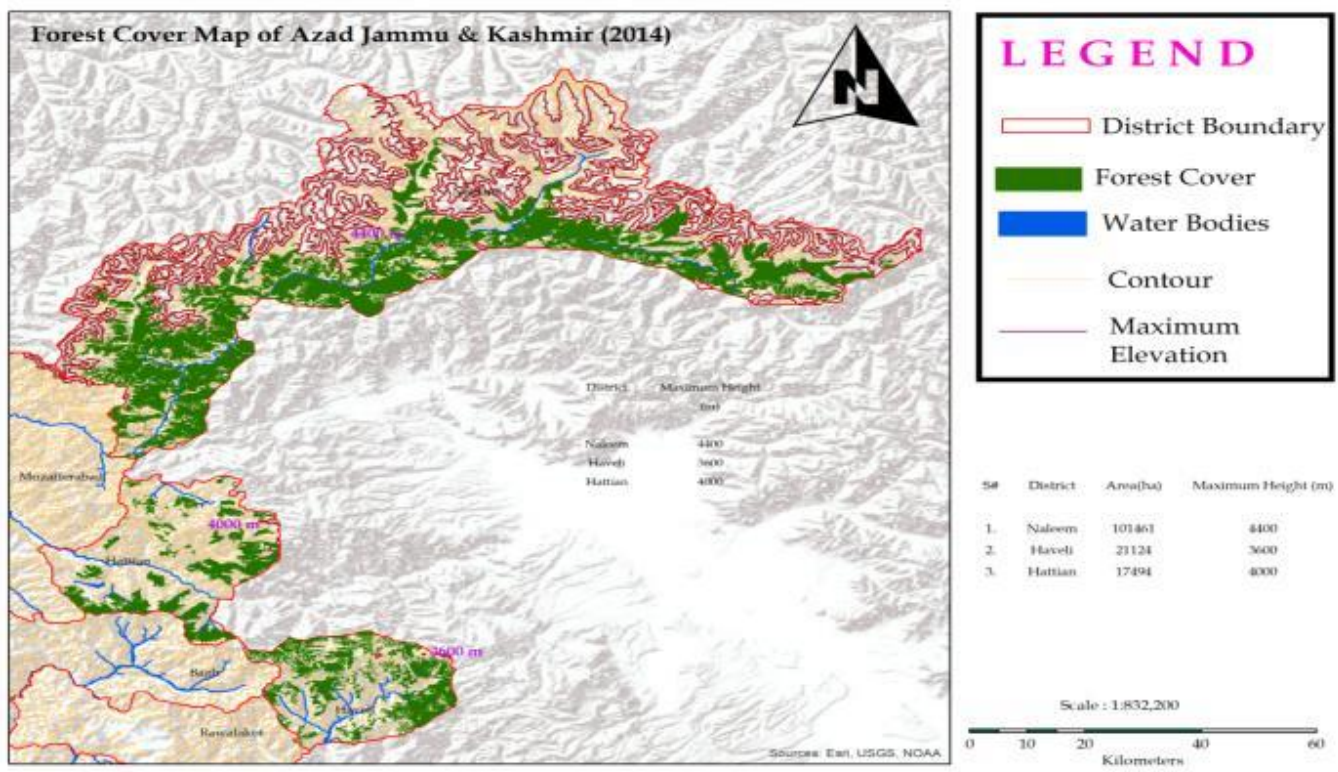

Figure 4. Forest cover \& elevation map of Azad J. \& Kashmir (AJK) for 2014 


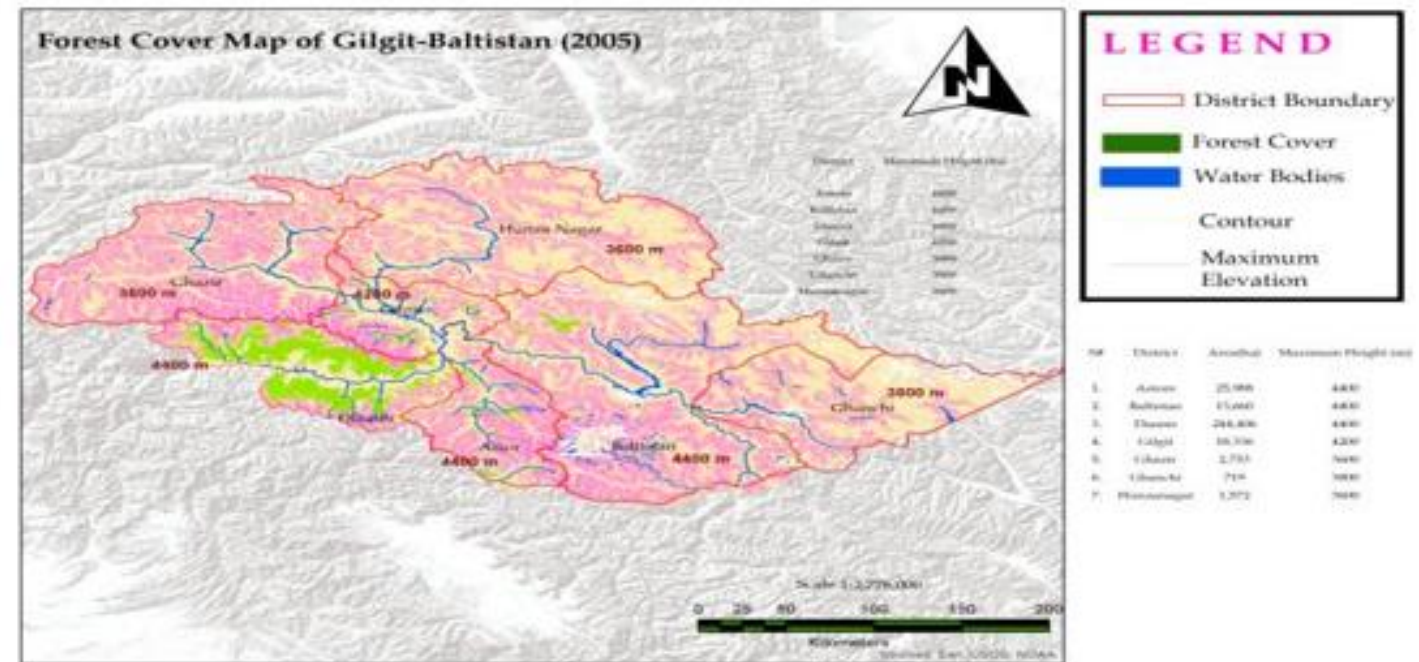

Figure 5. Forest cover \& elevation map of Gilgit Baltistan (GB) for 2005
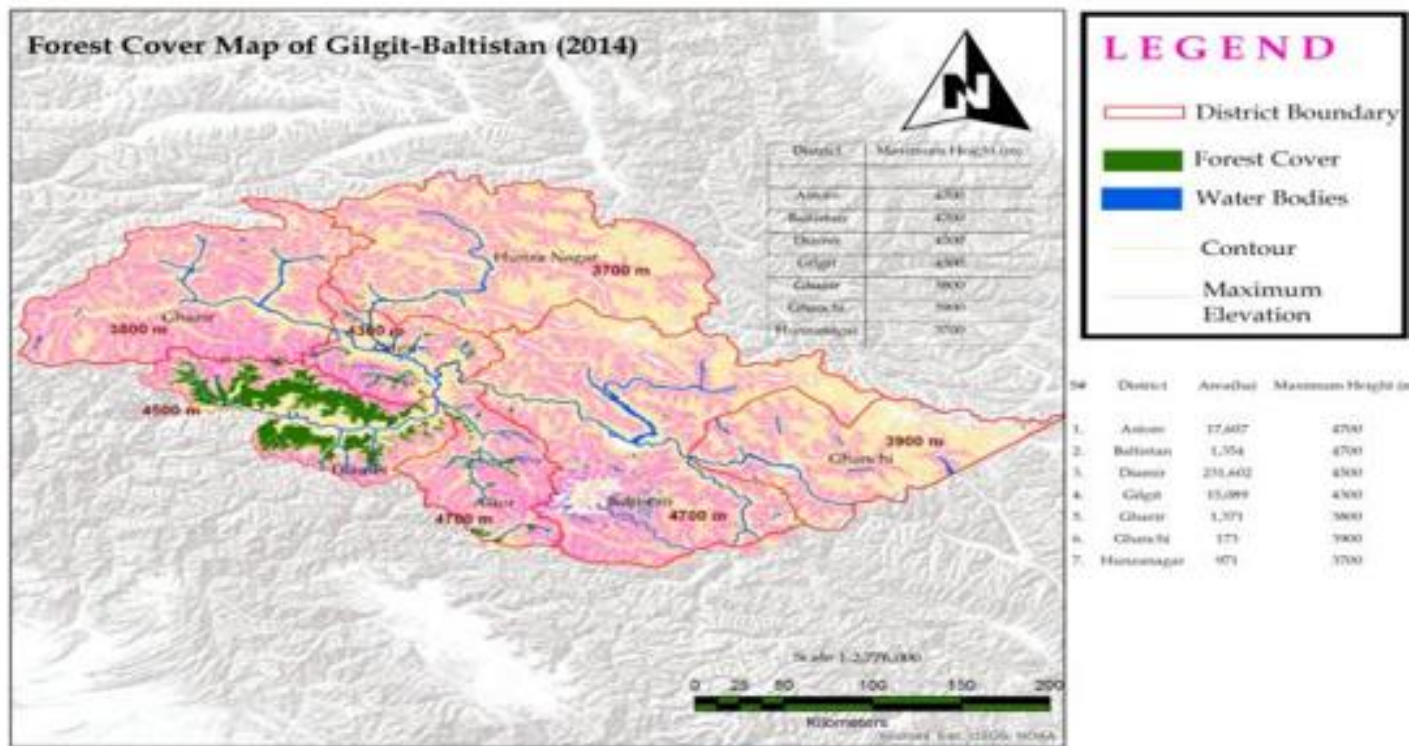

Figure 6. Forest cover \& elevation map of Gilgit Baltistan (GB) for 2014

Table 1. Province wise comparison for forest cover change (2005-2014)

\begin{tabular}{|c|c|cc|}
\hline S\# & Province & Elevation Change (m) \\
\hline 1. & KPK & + \\
\hline 2. & AJK & +233 \\
\hline 3. & GB & +170 \\
\hline & Total & +688 \\
\hline & Average & +230 \\
\hline
\end{tabular}


Table 2. Province wise comparison for forest elevation change (2005-2014)

\begin{tabular}{|c|c|c|c|c|c|}
\hline S\# & Province & $\begin{array}{c}\text { Forest Cover } \\
\text { (2005)(ha) }\end{array}$ & Forest Cover 2014(ha) & Change (Ha) & Change Percentage \\
\hline 1. & KPK & 961309 & 818529 & -142780 & $15 \%$ \\
\hline 2. & AJK & 163196 & 140079 & -24990 & $15 \%$ \\
\hline 3. & GB & 307,434 & 268167 & -39267 & $13 \%$ \\
\hline \multicolumn{2}{|c|}{ Total } & 1431939 & 1226775 & \multicolumn{2}{|c|}{$\begin{array}{c}\mathbf{2 0 7 0 3 7} \\
(\mathbf{1 4} \%)\end{array}$} \\
\hline
\end{tabular}

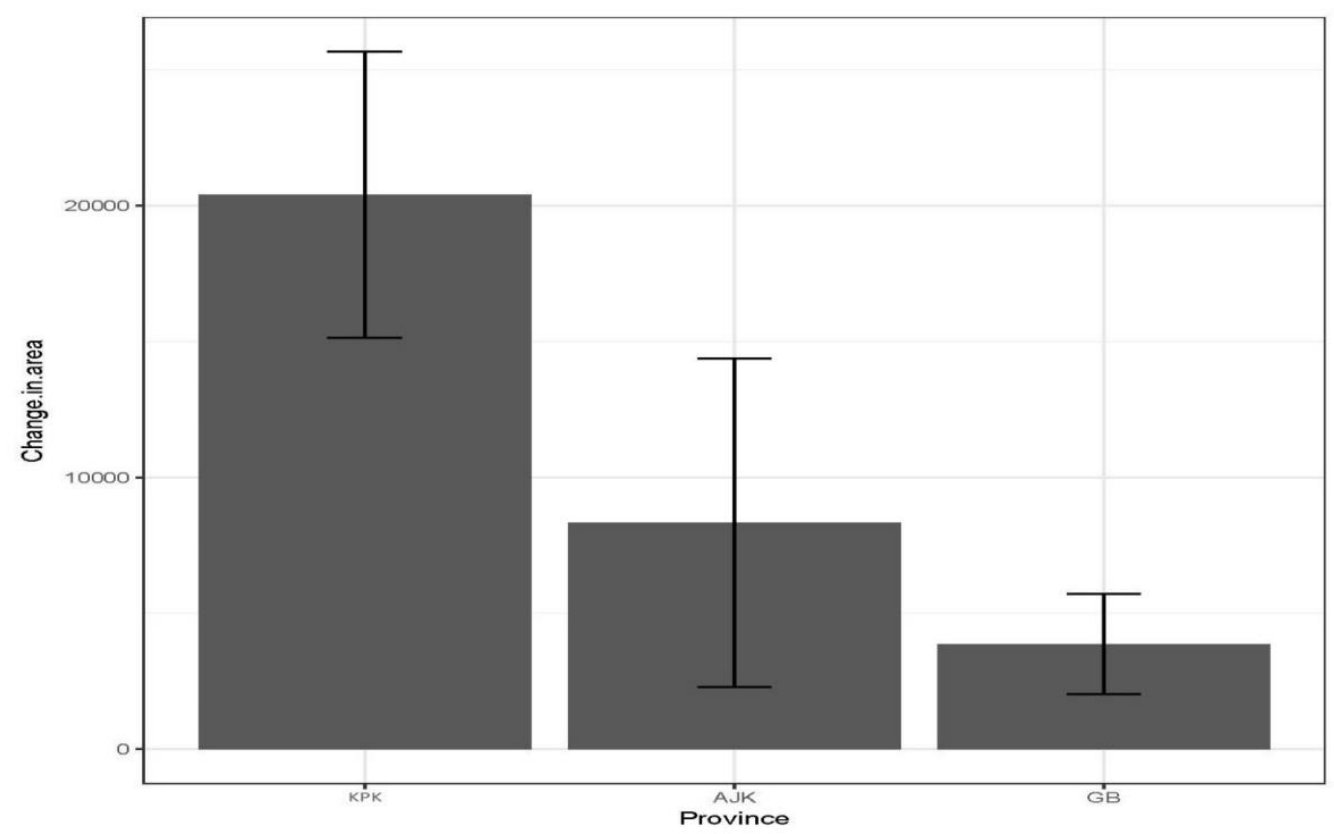

Figure 7. Showing the statistics of province wise comparison for forest cover change (m) using Fisher's LSD test

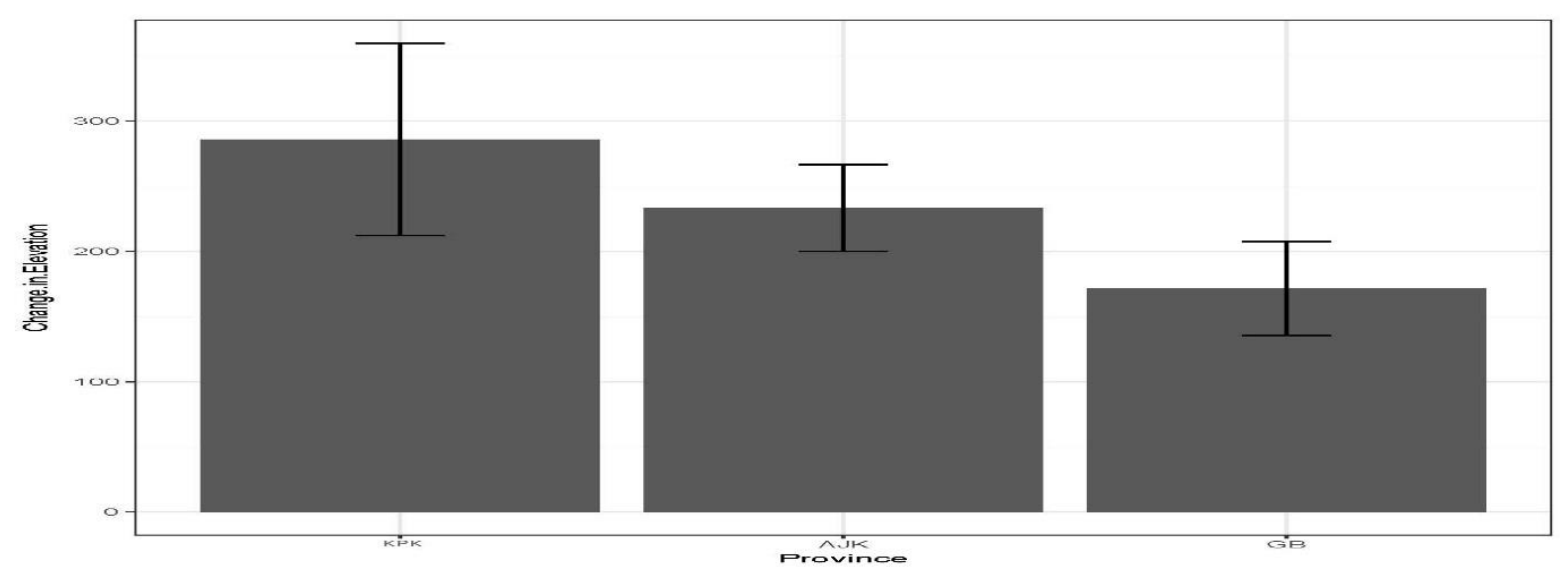

Figure 8. Showing the statistics of province wise comparison for forest elevation change (m) using Fisher's LSD test 
Table 3. Change detection $1980-2013 \mathrm{~T}(\max ){ }^{\circ} \mathrm{C}$

\begin{tabular}{|c|c|c|c|c|c|c|}
\hline Season & S1 & S2 & S3 & S4 & Change(1980-2013) & Change Per Year \\
\hline AJK & 1.5 & 0.7 & 0.5 & 0.7 & 3.4 & -1.8 \\
\hline GB & -1 & 0.3 & -1.7 & 0.6 & 0.6 & $\mathbf{2 . 2}$ \\
\hline KPK & 1 & 0.1 & 0.1 & -0.6 & Total & .06 \\
\hline
\end{tabular}

Table 4. Change detection 1980-2013 [T (min) ${ }^{\circ} \mathrm{C}$

\begin{tabular}{|c|c|c|c|c|c|c|}
\hline Season & S1 & S2 & S3 & S4 & Change(1980-2013) & Change Per Year \\
\hline AJK & -2.1 & -0.5 & 0.3 & 0.3 & -2.0 & \\
\hline GB & -1.2 & -0.2 & 0.3 & -0.4 & -1.5 & -2.0 \\
\hline KPK & $-2 . .0$ & 2.2 & -1.2 & -1.0 & $\mathbf{- 5 . 5}$ & $\mathbf{0 . . 1 7}$ \\
\hline
\end{tabular}

Table 5. Change detection 1980-2013 Precipitation (mm)

\begin{tabular}{|c|c|c|c|c|c|c|}
\hline Season & S1 & S2 & S3 & S4 & Change(1980-2013) & Change Per Year \\
\hline AJK & 41.9 & 35.2 & 25.5 & 14.1 & 88.5 & \\
\hline GB & -6.8 & 5.3 & 3 & -2.5 & -3.7 & \\
\hline KPK & 8.9 & 35.1 & 27.3 & 4.2 & $\mathbf{4 . 9}$ \\
\hline
\end{tabular}

S1 (Winter Dec-Jan-Feb), S2 (Spring March-April-May), S3 (Summer June-July-August),

S4 (Autumn Sep-Oct-Nov)

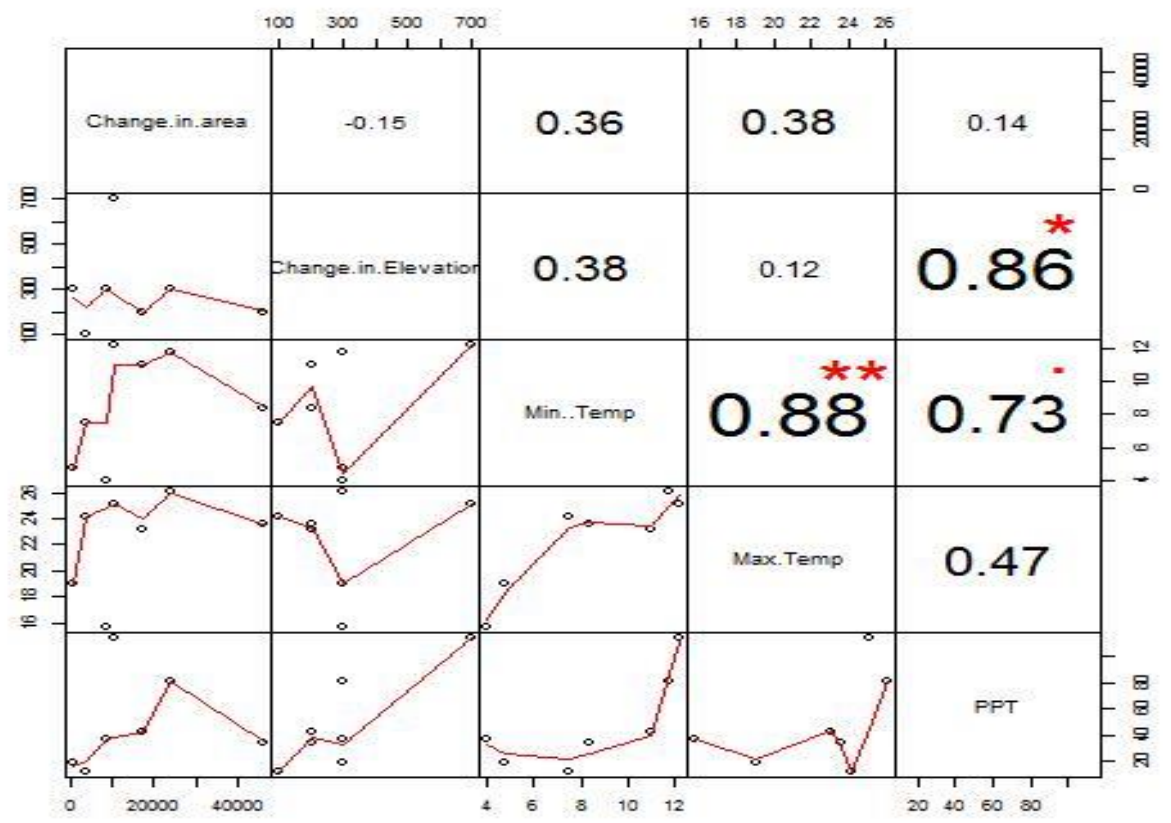

Figure 9. Pearson's correlation co-efficient for $\mathrm{T}(\max ), \mathrm{T}(\mathrm{min})$, Precipitation, change in forest cover area \& change in elevation 
Another argument for such high values of projected deforestation can be lack of expertise or carelessness in handling the satellite image and Google earth maps, application of GIS/RS software and interpretation of the data etc. It is also quite possible that due to upward shifting of timber line regeneration areas might be excluded from the forest cover because of more resemblance to shrubs rather than trees. The results were in consistency with Jose et al. (2008) tested the current position of timberline using GIS techniques. In case of prevailing timberline, it was found at lower levels as compared to the point, it can be. It can be said safely that rate of decreasing in forest cover area might not had been $45.9 \%$ for the last 33 years as calculated in the study but there was definitely a decrease in extent of forests of timberline.

Climatic factors of $\mathrm{T}(\max ), \mathrm{T}(\min ) \&$ Precipitation along with change in forest cover area \& rise in elevation were used as predictors for spatio-temporal dynamics of timberline in consistency with Weisberg et al. (2013) considered the biophysical factors (slope steepness, shrub cover etc.) to predict timberline changes, Jobbagy and Jackson, (2000) explored the processes that underlie the connection between environmental dynamics and the timberline, and also generally found the thermal regime as the most influential clarification for the potential position of tree line.

In province wise comparison, increase in Avg. $\mathrm{T}(\max )$ was $2.2^{\circ} \mathrm{C}$, decrease in Avg. $\mathrm{T}(\mathrm{min})$ is $5.5^{\circ} \mathrm{C}$ while Precipitation showed a total increase of $160.3 \mathrm{~mm}$ with many fluctuations during 1980 2013. The highest change for $\mathrm{T}(\max ), \mathrm{T}(\min ) \&$ Precipitation was observed in AJK as $3.4^{\circ}$, in AJK \& $\mathrm{KPK}$ as $-2^{\circ} \mathrm{C}$ and in $\mathrm{AJK}$ as $88.5 \mathrm{~mm}$ respectively. The lowest change for $\mathrm{T}(\max ) \& \mathrm{~T}(\min )$ was observed in $\mathrm{KPK}$ as $0.6^{\circ} \&$ in $\mathrm{GB}$ as $-1.5^{\circ} \mathrm{C}$ respectively. The lowest even a negative trend was observed in GB for Precipitation as $-3.7 \mathrm{~mm}$. Chaudhry et al. (2014) calculated a similar warming trend in temperature as +1.15 to $+1.25^{\circ} \mathrm{C}$ and +0.15 to $0.24{ }^{\circ} \mathrm{C}$ between 1960 and 2007 for Balochistan \& Khyber Pakhtunkhwa respectively, strongly promoting global heating and climate change. The results were also similar to Ahmad et al. (2009) investigated a somewhat chilling trend over KPK at a rate of $0.15^{\circ} \mathrm{C} /$ decade.

The correlation among climatic factors included in the study was strong and positive indicating that the change in one will definitely affect the others. Lal et al. (2011) concluded that temperature plus precipitation changes, melting of the glaciers, degeneration of natural and environmental resources were the main events distressing the people of the entire universe. Siddiqui (1997) anticipated that change in the physical and chemical nature of the earth's climate was possible to encompass dominating impact on the forests and related ecosystems particularly in alpine and sub-alpine zones constituting timberline. The correlation among Ppt-change in elevation was again strong and positive indicating that with the change in elevation, the Precipitation will definitely show variation. With change in Precipitation depending upon change in elevation, change in $T(\max ) \& \mathrm{~T}(\min )$ will be complementary. Korner and Paulsen, (2004) recognized that the site of tree line was principally determined by temperature, in addition to various other modulating agents. They further concluded that natural tree lines were climate-driven eco-tones, Schworer et al. (2014) suggested that mountain vegetation was highly susceptible to changing temperature and expected to shift upward towards the poles, simultaneously recent paleo-ecological studies have discovered that localized variation in the uphill shift of timberlines in the European Alps was most likely caused by a climatic gradient, Landclim being a vegetation model used under diverse climatic and physical scenarios around Swiss Alps projected a rapid uphill shift of mountainous vegetation areas by $500 \mathrm{~m}$ by the end of proceeding century, Svendsen and Kunkel, (2009) reported that numerous natural habitats were shifting towards poles as a consequence of changing climate, Schumacher and Bugmann, (2006) concluded that climate change with all its aspects had exerted major effects on mountain forests of European Alps, Sujata $e t$ al. (2015) has pointed out the changes in forest types and composition and extinction of animal and plant species as an aftermath of climate change. Svajda et al. (2011) wrote that mountainous ecosystems were specifically susceptible to climate change because all aspects of the resource in question (composition, diversity and production) were directly linked with temperature. Bogaert et al. (2011) studied the position of the tree line in a sub-Arctic region at various temporal and spatial scales 
and projected that tree line will rise was a consequence of climate warming, Schworer et al. (2014) suggested that mountainous vegetation was highly susceptible to temperature with an upward shift in tree line. Richardson et al. (2009) said that temperature-based theories appear to be the most reasonable for describing timber line dynamics because of its impact on variety of physiological processes along with micro site environment and ecological facilitation for booming regeneration, which was a precondition for uphill progression of tree line. It concludes that upward shift of forests of timberline of Pakistan was definitely dependent on climatic factors. There exist a negative but week correlation among change in area-change in elevation, concluding that timberline forest area will reduce with rising elevations and vice versa. The correlation among $\mathrm{T}(\max ), \mathrm{T}(\min ) \& \mathrm{Ppt}$. - change in forest cover area was found poor. It concluded that change in forest cover area was weakly and negatively related to change in elevation while it was poorly related to climatic factors.

\section{Conclusions}

Present study highlighted the importance of monitoring of renewable natural resources like forests with the application of ever increasing use of modern GIS/RS tools \& methods in recording vegetation land cover area, extracting extent of various forest types, detecting the changes in forest area cover as well as upward shifting over time in prevailing climate change phenomena and under current socioeconomic situations for scientific sustainable future forest management in Pakistan. These conclusions were supported by the scientist all over the world in their researches. The conclusions strongly recommend the wise and efficient amalgamation of GIS/RS techniques in mapping the extent, detecting the ongoing changes and devising appropriate strategies for scientifically organizing the natural resources. The resultant findings can be used in improved scientific forest management leading to enhanced forest eco-systems conservation (both protection as well as production). Environmental and climatic benefits of forest can also be highlighted purposefully using GIS/RS techniques.

Climate warming was a reality for timberline area of Pakistan as worldwide. Climatic factors including $\mathrm{T}(\max ), \mathrm{T}(\mathrm{min})$ \& Precipitation were not only connected strongly with each other but also with forest elevational shift. The change in forest cover area has the weakest relation to the variation in climatic factors and seems to be an entirely anthropogenic matter. Even then, timberline forests were diminishing in area and shifting upward was a fact. This reduction in forest cover will definitely result in reduced timber production and concerns regarding the applied forest management systems, opening new research avenues for future projections on forest management, preservation and conservation.

\section{References}

1.ADEDJI, O., TOPE-AJAYI, O. O., ABEGUNDE, O. L., Assessing and predicting changes in the status of Gambari Forest Reserve, Nigeria using Remote Sensing and GIS Techniques. Journal of Geographic Information System, (7), 2015, 301-318.

2.AHMAD, I., ZHAOBO, S., WEITAO, D., AMBREEN. R., Trend analysis of January temperature in Pakistan over the period of 1961-2006: Geographical Perspective. Pakistan Journal of Meteorology, 7(13), 2209, 11-22.

3.BOGAERT, R.V., HANECA, K., HOOGESTEGER, J., JONASSON, C. DAPPER, M., CALLAGHAN, T., Tree line shifts and disturbance events for sites studied in the Torneträsk area of sub-Arctic Sweden for the period 1800-2009, 2011, 93-101.

4.BUKHARI, S.S.B., HAIDER, A., LAEEQ, M. T., Landcover Atlas of Pakistan. Pakistan Forest Institute, Peshawar. The Printman Printers, Peshawar, 2012, 13-18.

5.CHAUDHRY, Q. Z., MAHMOOD, A., RASUL, G., AFZAAL, M., Climate Change Brief: Climate indicators of Pakistan. Pakistan Meteorological Department, Technical Report No. PMD-22/2009, 2014, 33-87.

6.DUTTA, P. K., DUTTA, B. K., DAS, A. K., SUNDRIYAL, R. C., Alpine timberline research gap in Himalaya: A Literature Review. The Indian Forester, 140(4), 2014, 133-145. 
7.ICIMOD, ICIMOD's Position on climate change and mountain systems - the case of the Hindu Kush - Himalayas. Mountain Research and Development, 28(3), 2008,:328-331.

8.JOBBAGY, E. G., JACKSON, R. B., The vertical distribution of soil organic carbon and its relation to climate and vegetation. Ecological Applications, 10, 2000, 423-436.

9.JOSE, M. N., BATLlORI, E., CARRILlO, E., CARRRERAS, J., FERRE, A., GUTIERREZ. E., Timberline structure and limited tree recruitment in the Catalan Pyrenees. Plant Ecology \& Diversity, 1(1), 2008, 47-57.

10.KHATTAK, M. S., REHMAN, S., SHOUKAT, K., KHAN, M. A., Analysis of land use changes using RS and GIS techniques: A case study of district Peshawar-Pakistan. IJERT, 2015, 4(10): 375382.

11.KLINGE, M., BOHNER, J., LEHMKUHL, F., Climate pattern, Snow and Timberlines in the Altai Mountains, Central Asia. Erdkunde, 57, 2003, 296-308.

12.KORNER, C.PAULSEN. J., A world-wide study of high altitude treeline temperatures. Journal of Biogeography, 31(5), 2004, 713-732.

13.LAL, R., SIVAKUMAR, M. V. K., FAIZ, M, A., RAHMAN, A., ISLAM. K. R., Climate change and food security in South Asia, 2011, 3-12.

14.LEADS Pakistan. Climate Change: Emerging Issues and Recommendations for Pakistan, 2009, 37 41.

15.MACCHI, M., Climate Variability and Change in the Himalayas. Framework for community-based climate vulnerability and capacity assessment in mountain areas. Kathmandu, Nepal: ICIMOD, 2011, 73- 83.

16.MAMET, S. D., CAIRNS, D. M., BROOK, R, K., KERSHAW, G. P., Modeling the spatial distribution of subarctic forest in northern Manitoba using GIS-based terrain and climate data. Physical Geography, 36(2), 2015, 93-112.

17.MCCALL, M. K., MINANG, P. A., Assessing Participatory GIS for Community-based Natural Resource Management: claiming community forests in Cameroon. The Geographical Journal, 171(4), 2015, 340-356.

18.MIFTA-UL-SHAFIQ, A., MIR, A., RASOOL, R., SINGH, H., AHMAD, P., A Geographical Analysis of Land Use/Land Cover Dynamics in Lolab Watershed of Kashmir Valley, Western Himalayas Using Remote Sensing and GIS. Journal of Remote Sensing \& GIS, 6, 2017, 189.

19.MIHAI, B., A Study of Alpine, Subalpine, and Forest Landscapes in the Iezer Mountains, Southern Carpathians. Mountain Research and Development, 27(3), 2007, 250-258.

20.MITASOVA, H., HOFIERKA, J., ZLOCHA, M., IVRSON, L. R., Modelling topographic potential for erosion and deposition using GIS. International Journal of Geographic Information Systems, 10(5), 1996, 629-641.

21.OLOKEOGRUN, O. S., IYIOLA, K., IYIOLA,O. F., Application of remote sensing and GIS in land use/land cover mapping and change detection in Shasha forest reserve, Nigeria. International Archives of the Photogrammetry, Remote Sensing and Spatial Information Sciences, Volume XL-8, 2014, 613-616.

22.RABINDRA, K. P., KALE, M. P., DUTTA, U., MISHRA, A., BANERJEE, B., SINGH, S., Forest cover change detection of Western Ghats of Maharashtra using satellite remote sensing based visual interpretation technique. Current Science, vol-98, No.5, 2010, 657-664.

23.RAWAT, J. S., KUMAR, M., Monitoring land use/cover change using remote sensing and GIS techniques: A case study of Hawalbagh block, district Almora, Uttarakhand, India. Egyptian Journal of Remote Sensing and Space Science, 18, 2015, 77-84.

24.RAZA, A., RAJA, I. A., RAZA, S., Land-Use Change Analysis of District Abbottabad, Pakistan: Taking advantage of GIS and Remote Sensing Analysis. Science Vision, 18(1\&2), 2012, 43-50.

25.RECHSTEINZER, C., ZELLWEGER, F., GERBER, A., BREINER, F, T., BOLLMAN, K., Remotely sensed forest habitat structures improve regional species conservation. Remote Sensing in Ecology and Conservation, 3(4), 2017, 247-258. 
26.R CORE TEAM, R: A language and environment for statistical computing. R Foundation for Statistical Computing, Vienna, Austria, 2016. URL: https://www.R-project.org/.

27.RICHARDSON, A.D., BRASWELL, B. H., HOLLINGER, D. Y., JENKINS, J. P., OLLINGER, S. $V$., Near-surface remote sensing of spatial and temporal variation in canopy phenology. Ecological Applications, 19, 2009, 1417-1428.

28.SAKHTIVEL, R., MANIVEL, M., JAWAHARRAJ, N., PUGALANTHI, V., RAVICHANDRAN, N., ANANAD, V. D., Remote sensing and GIS based forest cover change detection in Kalrayan hills, Tamil Nadu. Journal of Environmental Biology, 31(5), 2010, 737-747.

29.SCHUMACHER, S., BUGMANN, H., The relative importance of climatic effects, wildfires and management for future forest landscape dynamics in the Swiss Alps. Global Change Biology 12, 2006, $1435-50$.

30.SCHWORER, C., HENNE, P. D., TINNER, W., A model-data comparison of Holocene timberline changes in the Swiss Alps reveals past and future drivers of mountain forest dynamics. Global Change Biology, Vol., 20, 2014, 1512-1526.

31.SHEIKH, S. A., QURAT UL AIN, A., RUKHSANA, A, J., Tahir, M., Decline of Conifer forest cover in Pakistan: A GIS approach. Pak. J. Bot., 44(2), 2012, 511-514.

32.SIDDIQUI, K. M., Forestry and Environment. A book published by Pakistan Forest Institute, Peshawar, 1994, 1-34.

33.SIDDIQUI, K. M., MOHAMMAD, I., AYAZ, M., Forest ecosystem climate change impact assessment and adaptation strategies for Pakistan, Pak. Jour. of Forestry, 1991, 89-105.

34.SIMOONGA, C., UTZINGER, J., BROOKER, S., VOUNASTOU, P., APPLETON, C. C., STENSGAARD, A. S., OLSEN, A., KRISTENSIN, T. K., Remote sensing, geographical information system and spatial analysis for schistosomiasis epidemiology and ecology in Africa. Parasitology, 136(13), 2009, 1683-93.

35.SONTI, S. H., Application of Geographic Information System (GIS) in Forest Management. Journal of Geography \& Natural Disasters, 5, 2015, 145.

36.SUJATA, U., SHARMA, J., JAYARAMAN, M., KUMAR, V., RAVINRANATH, N. H., Climate change impact and vulnerability assessment of forests in the Indian Western Himalayan region: A case study of Himachal Pradesh, India. Climate Risk Management, vol-10, 2015, 63-76.

37.ŠVAJDA, J., SOLAR, J., JARINGA, M., BULAIK, M., Dwarf Pine (Pinus mugo) and selected abiotic habitat conditions in Western Tatra Mountains. Mountain Research and Development, 31(3), 2011, 220-228.

38.SVENDSEN, M., Kunkel, N., Water and adaptation to climate change, Rural 21 43(4), 2009, 8-12. 39.TAN, L., MU-YI, K., Primary study on Alpine timberline of Helan Mountain using GIS and RS. Journal of Natural Resources, 31(6), 2016, 973-981.

40.WEISBERG, P. J., SHANDRA, O., BECKER, M. E., Influences of climate and land use history on forest and timberline dynamics in the Carpathian Mountains during the twentieth century. Arctic, Antarctic and Alpine Research, 45(3), 2013, 404-414.

$\overline{\text { Manuscript received: } 9.04 .2020}$ 